\title{
Potential of e- and m-health tools and gender-tailored approach in modern model of education and prevention of cardiovascular disease in women
}

\author{
Potencjał e- i m-zdrowia oraz sprofilowanego do potrzeb i oczekiwań płci \\ podejścia w bardziej efektywnej edukacji zdrowotnej i prewencji \\ chorób sercowo-naczyniowych u kobiet \\ Joanna M. Zembala-John1,2,3, Adam P. Konka² \\ ${ }^{1}$ Silesian Center for Heart Diseases in Zabrze, Poland, \\ 2Silesian Park of Medical Technology Kardio-Med Silesia, Zabrze, Poland \\ ${ }^{3}$ Department of Internal Medicine, School of Public Health in Bytom, Medical University of Silesia, Katowice, Poland
}

\section{ABSTRACT}

Cardiovascular disease (CVD) is a leading cause of death worldwide. Only in 2012 it accounted for 17.5 million deaths. Although it affects both sexes, every year more women die due to CVD, more than due to all cancers, tuberculosis, HIV/AIDS and malaria combined. The risk factors, symptoms and course of CVD in women and men often differ, which makes early proper diagnosis and treatment more difficult. Despite being a major threat for women, the level of awareness and knowledge on the gender-specific picture of CVD, both among females and within the medical environment, remains staggeringly low.

Introducing a new gender-tailored health education and prevention model, adjusted to the medical, socio-cultural, technological expectations and needs of contemporary women, to their modern lifestyle and pace of life, could constitute an attractive and more effective alternative to initiatives undertaken so far targeting the general population.

E- and m-health tools seem to have a promising potential in educating and supporting contemporary women in their everyday health management. Applying Internet-based solutions together with a gender-oriented approach could increase the level of knowledge and CVD awareness among women, lead to improvement of their heart health and contribute to a reduction in the medical-social-economic burden of CVD in women.

KEY WORDS

health education, prevention, women, cardiovascular disease, e-health, m-health

\footnotetext{
Received: 06.09.2017

Revised: 29.09 .2017

Accepted: 03.11.2017

Published online: 16.10 .2018

Address for correspondence: Mgr Joanna M. Zembala-John, Silesian Center for Heart Diseases in Zabrze, ul. M. Curie-Skłodowskiej 9, 41-800 Zabrze, Poland, tel. + 483237337 91, e-mail: j.zembala-john@sccs.pl

Copyright $\odot$ Śląski Uniwersytet Medyczny w Katowicach

www.annales.sum.edu.pl
} 


\section{STRESZCZENIE}

Choroby sercowo-naczyniowe (ChSN) stanowią najczęstszą przyczynę zgonów na świecie. Tylko w roku 2012 z powodu ChSN zmarło 17,5 miliona osób. Mimo że problem ten dotyczy przedstawicieli obu płci, każdego roku więcej kobiet umiera z powodu chorób układu krążenia. Śmiertelność z powodu ChSN w tej grupie jest wyższa niż z powodu nowotworów, gruźlicy, HIV/AIDS i malarii łącznie. Symptomatyka i przebieg ChSN u mężczyzn i kobiet są często odmienne, w przypadku kobiet objawy są często mniej charakterystyczne i w związku z tym trudniejsze do wczesnego rozpoznania i leczenia. Poziom wiedzy i świadomości na temat specyfiki ChSN u kobiet w Polsce jest wciąż ograniczony i często trudno dostępny - zwłaszcza wśród samych zainteresowanych.

Wprowadzenie nowego modelu edukacji i prewencji, skierowanego wyłącznie do kobiet, skrojonego do ich potrzeb: biologicznych, medycznych, technologicznych, estetycznych, uwzględniającego społeczno-kulturowe uwarunkowania i oczekiwania może stanowić wartościową i bardziej skuteczną strategię prewencji ChSN w tej populacji.

Ponadto wykorzystanie w tym modelu nowych technologii, w tym narzędzi e- oraz m-zdrowia, bardziej dopasowanych do mobilnego stylu i tempa życia współczesnej kobiety, w profilaktyce ChSN mogłoby przyczynić się do zwiększenia wiedzy i świadomości na temat kobiecego profilu ChSN, poprawy sytuacji zdrowotnej kobiet w Polsce, a tym samym do redukcji medyczno-ekonomicznego i społecznego ciężaru ChSN w tej populacji.

\section{SŁOWA KLUCZOWE}

edukacja, kobiety, prewencja, choroby sercowo-naczyniowe, e-zdrowie, m-zdrowie

\section{INTRODUCTION}

\section{Epidemiology of cardiovascular disease}

Cardiovascular disease (CVD) is a leading cause of mortality, morbidity and disability worldwide. Only in 2012 it accounted for 17.5 million deaths, which constitutes almost $31 \%$ of the total global mortality [1]. In Europe in 2013 an estimated $42 \%$ of all deaths were due to CVD [2]. Despite improvement in the overall outcomes $[3,4,5]$, a significant rise in health awareness, as well as advances in diagnostics and treatment, the scale of the problem is still increasing. According to the report by the World Health Organization (WHO) and World Heart Federation (WHF), by 2030 the global number of CVD deaths will rise to 23.6 million [6,7]. Epidemiologists and researchers speak today about a CVD pandemic, particularly ischemic heart disease and heart failure [8,9].

CVD is the leading cause of mortality also in Poland. In $201345.8 \%$ of deaths (more than 177000 people) were caused by CVD [10]. Approximately 476 Polish people die from CVD every day, every 5 - prematurely [11]. Poland occupies the 14th position on the list of the highest standardized European Union mortality rate due to ischemic heart disease [12].

Although CVD is a main cause of death for both men and women, it is widely considered a men's disease. Statistics confirm, however, that it constitutes a greater threat for women: every year more women die due to CVD, more than due to all cancers, tuberculosis, HIV/AIDS and malaria combined [13].

The purpose of this paper is to address the problem of CVD among women, to present the female-specific risk factors, symptoms and course of CVD, to highlight the significance and value of a gender-tailored approach in more effective education and CVD prevention. Moreover, the authors aim to investigate the potential of e- and m-health in modern health management and to present the concept of their authorial program - the "FitPolka" project, dedicated to CVD education and prevention in women.

\section{Cardiovascular disease in women}

Cardiovascular disease is the leading cause of death for women throughout the world [14,15], claiming the lives of 8.6 million women each year, which equates to one third of all deaths in women worldwide [16]. In Poland in 2013, 95000 deaths $(51 \%)$ among women were attributed to CVD. Although it is widely considered a male disease, the mortality in this population is significantly lower - in 2013 it was 82500 men $(41 \%)$ [10]. It is estimated that every day approximately 250 Polish women die from CVD [17].

\section{Feminine profile of cardiovascular disease}

The symptoms and course of CVD in women and men often differ, which makes early proper diagnosis and treatment more difficult $[18,19]$. The manifestation of feminine myocardial infarction (MI) is often atypical (comparing to the "classic" MI picture, attributed widely to men): it may include shortness of breath, dizziness, lightheadedness, nausea, vomiting, jaw/back/shoulder/upper abdomen pain, feeling of extreme fatigue - symptoms often confused with com mon gastric disorders or musculoskeletal pain caused by physical overload with everyday activities [15]. 
According to the Framingham Follow-up Study, MI remains more frequently clinically unrecognized in women than in men (27\% vs. $34 \%)$ [20]. Specialized diagnostics may fail - ECG results may not confirm the signs of ongoing MI. In approximately $20 \%$ of women with symptoms of acute coronary syndrome, coronary angiography does not reveal significant pathological changes in the great coronary vessels [21]. Approximately $50 \%$ of stress tests performed in female patients in diagnostics, among others, of coronary artery disease, give false positive results. Additionally, a non-clinical, yet significant obstacle in receiving proper and timely diagnosis and treatment frequently constitutes the feminine nature: women tend to belittle, disregard their health problems, believing they are the result of everyday stress, tiredness, casual psychophysical overload. This, together with a lack of knowledge on women specific CVD symptoms, results in a delay in seeking treatment - it is estimated that on the average a female patient with an acute heart condition gets to a doctor 30 minutes later than a male $[15,22,23]$.

Multiple studies confirm that interventional treatment in the female population is considered to be more difficult: the risk of complications (bleeding, vascular complications, other) and death is much higher than in men $[15,24,25]$. This observation leads to undertaking a different therapeutic approach: women with heart failure are less frequently referred to imaging diagnostics [19]; those with acute coronary syndrome are less frequently referred to invasive treatment [15,21]; when treated, their treatment outcomes are poorer: in-hospital and early mortality are significantly higher in comparison to men [15,26].

Nonetheless, according to the research of the American Heart Association (AHA), the higher risk of complications, peri- and postprocedural mortality in women is not directly associated with sex per se, but most of all with the fact that the average female patient at referral is usually 10 years older than the male (due to estrogen's protective effect lasting till the mid-40s - till menopause, therefore heart disease affects women approximately 10 years later than men), frequently with numerous co-morbidities hence their health profile at the moment of treatment is worse than men's [27]. The female sex itself is considered to be one of the risk factors associated with poor prognosis, complications and increased mortality, which led to inclusion of the sex category in risk calculators such as the EuroSCORE II algorithm (2011) or the CHA2DS2-VASc scale which evaluates ischemic stroke risk in patients with atrial fibrillation. The distinct, sex-related nature of CVD also applies to CVD risk factors, particularly to those modifiable ones, such as smoking, arterial hypertension, dyslipidemia, diabetes, overweight and obesity, a sedentary lifestyle and unhealthy nutrition. Although the overall number of risk factors is prognostic for both sexes, the prevalence and outcomes associated with individual risk factors differ in women and men [28]. This is particularly noticeable in the case of dyslipidemia and diabetes. The latter is associated with women with a significantly greater (even up to 7-fold) risk of coronary artery disease (compared to 2-3-fold in men) [29]. Hypertension increases the risk of myocardial infarction 3-fold in women (2-fold in men) [19]. Smoking is considered to be one of the most concerning health risk behaviors in females [30]. The risk of CVD in active smokers is higher, and additionally the risk is higher in females than in the male population 7 and 2.5 times higher than in nonsmokers, respectively [15]. Combining smoking with taking oral contraceptives (OC) by women over 35 years of age is particularly dangerous as it increases the probability of cardiovascular events [31].

Furthermore, the problem of overweight and obesity affects women more frequently than men, which is particularly noticeable in the older population. The European Health Interview Survey (EHIS), conducted in Poland in 2014 by the Central Statistical Office, revealed that nearly $46 \%$ of adult women in Poland had an abnormal - higher body mass: $30 \%$ were overweight, $16 \%$ - obese [32].

Aside from the abovementioned health risks, women face additional threats from other gender-related factors, such as pregnancy, menopause, the use of oral contraceptives or hormone replacement therapy [33]. In 2016 the European Society of Cardiology released new Guidelines on Cardiovascular Prevention in Clinical Practice, presenting more a complex approach to the CVD female profile. The authors underscored the association between obstetric and non-obstetric (polycystic ovary syndrome, premature menopause) conditions and the risk of developing CVD later in life [34]. Pre-eclampsia, for instance, increases the risk of hypertension and diabetes. Women with a history of pre-eclampsia have an approximately 2 -fold greater risk for subsequent ischemic heart disease, stroke and venous thromboembolic events over the 5 to 15 years after pregnancy [35]. Further research needs to be undertaken to firmly confirm such associations.

\section{Feminization of the elderly - quality of life of elderly women}

The world's population is growing older - this trend has been noticeable in every country in the world, Poland including. Since 1950 - the year the World Health Organization started collecting data on mortality and the causes of death [36], the life expectancy has increased by twenty years (in the years 1950-1955 the average world life expectancy was 48 years, in 2005 -2010 - 68 years). Between 2010-2015 WHO reported the fastest global rise in life expectancy since the 
1960s: according to the WHO Global Health Observatory, during that period the average life expectancy increased by 5 years worldwide [37]. Population ageing has become one of the most dominant global demographic trends: by 2050 the number of people aged over 60 is projected to increase to over 2 billion, representing $22 \%$ of the world population. Among the elderly the share of those aged 80 years and over was $14 \%$ in 2013 , by 2050 it is expected to triple, reaching 19\% (392 million people) [38].

In Poland in 2013 the population of seniors over 80 years of age comprised $3.9 \%$ of the whole population. It is predicted that by 2050 it will rise to $10.4 \%(3.5$ million people). $64 \%$ of this group will constitute women [39]. Data confirm that women live statistically longer than men. In 2014 the life expectancy for women in the European Union (28 EU states) was, on average, 5.5 years longer (83.6 years) than that for men (78.1 years) [40]. In 2015 the average life expectancy of a Polish woman was 81.6 years, while a Polish man - 73.6 [41]. Feminization of the elderly, recognized worldwide, is also observed in Poland: in the age group of $65+$, for every 100 men there were 157 women (2016), whereas among 85+-year-olds, for every 100 men there were 267 women, which constitutes $72.8 \%$ of the total population in that age range [42].

Increased longevity is frequently not matched by a healthy life expectancy, which is noticeable particularly in the female population. Although the healthy life years indicator (HLY) in women has remained at a similar level in the EU in the last few years, in Poland it has been declining: in 2005 it was 66.9 years for women, whereas in 2015 - 63.2 years [43]. Less than half of Polish women aged 50-59 describe their health as good or satisfying; more than $50 \%$ declare suffering from long-term health issues. The percentage of those satisfied with their health rapidly decreases with each decade of life [44].

Additional non-medical factors such as social isolation, loneliness, change in social status (widowhood), lack of financial security or even poverty, can adversely affect women's physical and mental health, leading to further health degeneration and a decline in their quality of life. The facts presented above stress the need for special focus on women's health across their life-span, taking into account biological, medical, socio-cultural and demographic determinants. A gender-oriented perspective should be adopted in the development of policy and interventions in order to design and implement more effective educational and preventive strategies and programs than to date, and to improve the health of future generations of elderly women. Greater emphasis also should be placed upon health education and disease prevention among women in all age groups: to make them aware in advance of the major CVD risk factors and female specific health conditions and provide them with knowledge and health self-management skills.

\section{Role and impact of CVD prevention}

Prevention is effective: scientific and clinical research confirm that properly addressed and conducted health education and disease prevention lead to a reduction in the clinical, social, and economic burden of CVD. The actions undertaken within the last thirty years have contributed to a reduction in morbidity and mortality due to CVD worldwide. $50 \%$ of the CVD risk factors are behavioral, strictly associated with one's lifestyle - hence modifiable. The decline in CVD mortality has been attributed primarily to the reduction in cholesterol and blood pressure levels as well as the number of smokers in the population. On the other hand, a significant rise in other CVD threats has been observed, particularly obesity and diabetes type 2. Eliminating risky health behaviors, as multiple studies confirm, would make it possible to prevent at least $80 \%$ of CVDs.

Although cardiovascular disease is considered to be the greatest health issue and threat for women, as health organizations and medical societies report, the level of awareness and knowledge on CVD in this group remains staggeringly low.

\section{Gender-tailored educational campaigns and prevention initiatives}

Worldwide social campaigns conducted since the XX century focused on the so-called "bikini area" [45] have led to a significant rise in awareness and knowledge regarding cervical and breast cancer among women. This in consequence has resulted in a noticeable global decline in the mortality rate among women due to these types of cancer. It would be worthwhile to use this know-how and to transfer this successful model of education and disease prevention from the oncological to the cardiovascular domain. A good example of gender-oriented prevention is the activity of the American movement "Go Red for Women". Launched in 2004 on the initiative of the American Heart Association (AHA), this program has undertaken actions dedicated to the problem of female CVD, by conducting modern social campaigns and running an interactive educational web platform (www.goredforwomen.org). According to the AHA report, the 10 years of the Go Red activity contributed to a significant rise in the awareness of American women on CVD risk factors and - in consequence - to a reduction in morbidity and mortality due to heart disease and cerebrovascular disease in women of $34 \%$ (more than 627 thousand women) $[35,46]$.

Not only the United States and AHA focus on CVD in women. The European Society of Cardiology (ESC) 
also has recognized the purposefulness of such initiatives, evidence of which is the program Women at Heart launched in 2005

Likewise, the Polish medical environment has undertaken actions to improve heart health in women. In 1997 the Polish Cardiac Society (Polskie Towarzystwo Kardiologiczne, PTK) appointed a separate section - the PTK Working Group on Women's Heart Diseases. Its main aim is to disseminate knowledge on the feminine profile of CVD in the medical environment and to deepen research on the specifics of heart diseases in women in Poland. Within the framework of its activity, the Section organizes numerous didactic sessions (examples include "Heart failure in women. How to prevent, how to treat", held during XX International Congress of the Polish Cardiac Society, Poznań 2016), cyclic scientific meetings on CVD in women, such as the conference "Zdrowie Kobiety" (Woman's Health), "Dilemmas and challenges arrhythmia in women" or the annual National Conference of the Polish Cardiac Society Section of Heart Disease in Women. Research on cardiovascular disease in women plays an important role in the Section's activity. The effects of this work are visible in numerous publications on women's heart health, among others 2 monographies prepared by Świątecka G., Kornacewicz-Jach Z. et al.: "Cardiovascular disease in pregnancy" and "Cardiovascular disease in women" as well as the cycle of 20 articles dedicated to acute coronary syndromes in women, written in cooperation with the Silesian Center for Heart Diseases in Zabrze on the basis of the National Acute Coronary Syndrome Registry (PL-ACS), initiated and conducted in Zabrze.

Furthermore, in 2006 on the initiative of the Editorial Board of the Polish Forum for the Prevention of Cardiovascular Diseases, the first consensus in Poland Guidelines on CVD in Women were elaborated.

The number of education and prevention programs, aimed both at the medical environment and community, has increased over the last few years worldwide, as well as in Poland, leading to positive changes in regard to morbidity and mortality among women due to CVD. Their range and impact, however, in view of the magnitude of the problem and new arising health threats (such as the obesity pandemic) seem to be insufficient. Effective solutions and initiatives addressed particularly to this group, to this disease, as well to the lifestyle and needs of contemporary women are still lacking.

\section{Potential of novel technologies in more effective CVD prevention in women}

Having in mind the global scale of CVD and epidemiological prognostics, more effective measures of health education and prevention among women should be undertaken.

Novel technologies, such as e- and m-health solutions bring an answer to the new expectations, socio-cultural and technological needs of contemporary women. They may constitute an excellent complement or - in justified cases - an alternative to traditional methods of education and prevention of civilization diseases, CVD including. From educational, interactive web platforms, through teleconsultations, mobile electronic diaries (m-diaries) to mobile applications related to health and healthy lifestyle - novel technologies may serve as a great support in primary and secondary prevention. They provide easy access to health education and care - anytime and anywhere, empowering users to have greater control over their health, figuratively and literally speaking: to take their health in their hands.

\section{M-Health solutions - new opportunities}

According to the WHO Global Observatory for e-Health, "e-health" is defined as "the cost-effective and secure use of information communication technologies (ICT) in support of health and health-related fields, including health-care services, health surveillance, health literature and health education, knowledge and research", whereas mobile health (m-health) is "the use of mobile devices - such as mobile phones, patient monitoring devices, personal digital assistants (PDAs) and wireless devices - for medical and public health practice" [47].

M-health solutions have become an attractive, valuable tool for health promotion and disease prevention $[48,49]$. They offer the ability to actively engage individuals in health care in ways that previously had not been possible: by becoming, a personal health assistant available 24/7 and a valuable partner in the health care shift towards a patient-centered delivery model [50]. Mobile technologies have the potential to increase patient's safety and the effectiveness of treatment, as well as improve his/her adherence and compliance to doctor's recommendations [48,51]. They facilitate the promotion of health and a healthy lifestyle by communicating - in a user friendly way, and a more convenient manner - prevention behaviors [52].

The m-health market has been one of the most dynamically developing areas worldwide. According to the report "mHealth Market by Devices, by Stakeholder, by Service, by Therapeutics, and by Applications: Global Industry Perspective, Comprehensive Analysis and Forecast, 2014-2022", within the years 2016-2022 it is expected to grow globally at a CAGR of $32.5 \%$. In 2014 the global m-health market was valued at 11.47 billion USD; it is prognosed that by 2022 it 
will be worth approximately 102.43 billion USD [53]. In 2016, 259000 mobile applications related to health were available on the major app stores [54]. It is predicted that the number of health apps will continue to rise dynamically in the next few years, with the global rise of the number of smartphone owners. In 2015 one billion people owned a smartphone. It is estimated that by 2020 there will be 2.87 billion smartphone owners worldwide; half of them will use health apps [48,55].

Health care providers as well as health insurance companies increasingly more frequently and willingly use personal devices (smartphones, tablets) and health-oriented software in their work, considering these solutions as a good tool to increase the scope and quality of their services, to monitor the process of treatment and health condition of their patients (particularly those with chronic conditions), to improve bilateral communication (doctor-patient), as well as to increase adherence and medical compliance [56].

From the health care payer's perspective, m-health solutions may lead to a reduction in the medical-social-economic burden related to the disease (seeing their potential in reducing the hospitalization ratio, the number of hospital re-admissions, temporary or permanent incapacity for work, disability, and death rates) $[48,57,58]$.

Last, but not least - from the patients' point of view, novel health solutions constitute an additional channel of education, a convenient tool supporting patients in their treatment process, in addition to health and risk factor management. Good quality m-health may increase patients' commitment, sense of security and responsibility for their own health (the concept of patient empowerment) [48,51].

\section{Novel technologies - challenges, barriers and limitations}

Digital interventions, m-health in particular, seem to hold a promising potential in health education, disease prevention and monitoring. Whether this potential transforms into effective action, a valuable tool genuinely useful and used in everyday practice, depends on numerous conditions. Among the key barriers, hindering and slowing down successful deployment of m-health, worth in particular stressing are: a lack of clearly defined standards, evidence-based guidelines, regarding, among others, quality and content reliability of the designed apps, the lack of a legal framework, data protection issues (including the confidentiality and security of personal health records). The latter is particularly considered to be of crucial importance; it has been legitimately indicated as a major concern. The transparency of privacy and confidentiality rules in $\mathrm{m}$-health is critical for building public trust [59].

For end-stage mobile-application users, one of the major concerns, besides the above mentioned security and data protection issues, constitutes the quality of health apps. The m-health market is crowded: according to the Research2Guidance report, "M-health app developer economics 2016", in 2016 there were 58000 mobile health app publishers [54] - from "garage" producers (small startups or sole traders) with great ambitions, an interesting concept but frequently limited know-how, to large corporations, rich in human/financial/scientific/technical resources and thus having a higher output potential. Today growth on the supply side exceeds the demand. This in consequence leads to the production of very diverse - in regard to quality and content reliability - products, which translates directly into their effectiveness and safety of use. Software can be erroneous, the applied algorithms selective, defective, misleading, and the interface too complicated, not user friendly, resulting in incorrect or even harmful use of the app. The quality of the content also varies: the strategies of user/patient management presented in health applications; the recommendations vary: from those evidence-based to doubtful, controversial or even unacceptable from the medical point of view, not backed up by evidence. The average consumer, with no medical background, frequently risks using a particular health app, as he/she is not able to verify and assess the medical reliability of the proposed contents.

To limit the risk and protect the user/potential patient, numerous initiatives - global, continental, national are being undertaken. Official programs of m-health app certification are being developed. Examples include the Health Apps Library (official website run by the United Kingdom National Health Care Service) or AppSaludable Distinctive (conducted by the Andalusian Agency for Healthcare Quality) [60]. Official public bodies, such as the European Commission or Food and Drug Administration, recognizing the rapid expansion, broad application and variety of health apps, their potential benefits but also risks, have been systematically analyzing the mobile health market, providing guidance documents, and gradually developing mobile health frameworks. The FDA for instance, systematically issues guidance for the mobile app industry, clarifying definitions (medical device vs. non-medical device software) and a subset of mobile apps which the FDA intends to control and to which apply its authority [61].

Moreover, lists of recommended reliable health apps are being published - an example is the first European catalogue - the European Directory of Health Apps. Some app stores offer only certified health applications - such as the health-focused app store Happtique [60].

An additional challenge - technology literacy, constitutes a barrier in effectively deploying m-health different in particular demographic groups, strongly linked to age (difference between the young genera- 
tion and seniors), the level of education, income or place of residence.

Elaborating evidence-based guidelines and fixed frameworks (regarding ethical, medical legal, financial issues), creating good practices, setting common indicators for app development and assessment, eventually exchanging interdisciplinary experiences, know-how, and points of view among different stakeholders such actions need to be undertaken in order to succeed in $\mathrm{m}$-health and elaborate safe and effective mobile solutions valued by patients, providers and payers; solutions genuinely useful and effective in modern health education and disease prevention.

\section{FitPolka project - rationale and design}

The magnitude of CVD prevalence among women worldwide, Poland including, and the lack of effective prevention programs on the Polish market, tailored to female's specific medical and socio-cultural needs, have led the author of this paper to develop the concept of "FitPolka" - an innovative, complex system of education and prevention of CVD in women, using eand $\mathrm{m}$-health tools. The innovativeness of the project lies in transferring traditional educational and preventive actions to the mobile level. The main aim and task of this project is to increase awareness among Polish women, to support them in their everyday fight against CVD by providing them with a reliable, easy-to-access source of knowledge on CVD and its management. The authors' intention and ambition is to arouse "heart health mindfulness" among women, to coach Polish women how to live more actively, healthier, how to improve their health condition and quality of life.

To achieve the abovementioned goals, the authors plan to design two tools that can be used independently or together - for an optimal effect, depending on the user's needs and preferences:

- Fit-m-Polka - a mobile application - a form of personal health assistant - health coach, available 24/7.

- Fit-e-Polka - an educational web-based platform, divided into 6 independent sections:

- healthy nutrition,

- physical activity,

- stress management,

- smoking cessation,

- health monitoring,

- health education.

The project will focus on two main areas, represented by two modules:

- risk assessment module - designed in the form of a virtual interview (patient-doctor) test will enable the user to check her estimated personal CVD risk,

- risk management module - depending on the outcomes of the CVD risk assessment, the user will receive certain recommendations to follow.
The concept of the "FitPolka" project is based on a few key assumptions:

1. A program designed and addressed to women: the elaboration of a targeted education and prevention program, dedicated exclusively to women. Both the (medical) content of the project as well as the communication strategy, design - graphic layout and interface will be tailored to women and their needs.

2. A complex, holistic approach to cardiovascular diseases: the idea of "FitPolka" is to support women at every turn and in every aspect of disease management: from a general guide on healthy lifestyle to information regarding risk factors, the female profile and symptoms of CVD, disease management, as well as primary and secondary prevention.

3. Improving accessibility to education on cardiovascular disease in women: by providing easy access to a reliable, high quality source of information on prevention and CVD management.

4. Personalized approach.

5. Integration of the mobile application with the educational web-based platform, based on the SMAC (social, mobile, analytics, cloud) concept.

To ensure high quality content, an attractive and user-friendly technological form and design, an interdisciplinary team of experienced cardiologists, diabetologists, epidemiologists dieticians, public health specialists, health psychologists, IT specialists and graphic designers will be established.

\section{SUMMARY}

Women's risk factors, symptoms and course of, as well as response to cardiovascular disease vary widely from those in men. Having in mind the current epidemiological situation of CVD in women, WHO prognostics as well as global trends such as demographic aging and feminization of the elderly, establishing a more effective, long-term strategy of education and CVD prevention in women is essential.

Gender-tailored health education and CVD prevention, adjusted on one side to the clinical profile of women, clinical picture of feminine CVD, and on the other - to the needs and lifestyle of contemporary women, may bring measurable benefits for patients, health providers and health care payers; it may have a great impact on reducing the growing medical-social-economic burden of CVD in women worldwide. Novel technologies, $\mathrm{m}$-health in particular, seem to hold a promising potential in this field - potential officially recognized and supported by many authorities, the United Nations, World Health Organization [62], international medical scientific societies and many others. 


\section{STATEMENT}

The "FitPolka" project received co-financing from the National Center for Research and Development within the framework of the program "Social Innovation II".
The concept of the project was created by the authors of this paper. The project will be conducted by the interdisciplinary consortium HeartApp Alliance, composed of the Foundation of the Silesian Center for Heart Diseases in Zabrze (as the leader), Silesian Center for Heart Diseases in Zabrze, Medical University of Silesia in Katowice, Silesian Park of Medical Technology Kardio-Med Silesia and Silvermedia S.A.

\author{
Author's contribution \\ Study design - J.M. Zembala-John (90\%), A.P. Konka (10\%) \\ Data collection - J.M. Zembala-John (70\%), A.P. Konka (30\%) \\ Data interpretation - J.M. Zembala-John (70\%), A.P. Konka (30\%) \\ Manuscript preparation - J.M. Zembala-John (70\%), A.P. Konka (30\%) \\ Literature research - J.M. Zembala-John (70\%), A.P. Konka (30\%)
}

\title{
REFERENCES:
}

1. Global Status Report on non-communicable diseases; World Heart Organization; Geneva 2014: 9.

2. Nicholas M., Townsend N., Scarborough P., Rayner M. Cardiovascular disease in Europe 2014: epidemiological update. Eur Heart J. 2014; 35(42): 2950-2959, doi: 10.1093/eurheartj/ehu299.

3. The burden of cardiovascular disease and diabetes. W: OECD (2015), Cardiovascular Disease and Diabetes: Policies for Better Health and Quality of Care. OECD Health Policy Studies, OECD Publishing, Paris 2015: 31-49, doi: 10.1787/9789264233010-en.

4. Oficjalna strona Eurostat - Statistics Explained. Eurostat - Statistics Explained > Causes of death statistics. http://ec.europa.eu/eurostat/statisticsexplained/index.php/Causes_of_death_statistics [dostęp: 10.05.2017].

5. Wilkins E., Wilson L., Wickramasinghe K., Bhatnagar P., Leal J., Luengo-Fernandez R., Burns R., Rayner M., Townsend N. European Cardiovascular Disease Statistics 2017. European Heart Network, Brussels 2017: 7-8.

6. Mendis S., Puska P., Norrving B. Evidence for prevention of heart attack and stroke. W: Global Atlas on Cardiovascular Disease Prevention and Control. World Health Organization (in collaboration with the World Heart Federation and World Stroke Organization), Geneva 2011: 16-18.

7. Smith S.C. Jr., Collins A., Ferrari R., Holmes D.R. Jr, Logstrup S., McGhie D.V., Ralston J., Sacco R.L., Stam H., Taubert K., Wood D.A. Zoghbi W.A. Our time: a call to save preventable death from cardiovascula disease (heart disease and stroke). J. Am. Coll. Cardiol. 2012; 60(22): 2343 -2348, doi: 10.1016/j.jacc.2012.08.962.

8. Anand S. A commitment to curbing the pandemic of cardiovascular diseases. Lancet 2000; 356(9226): 347, doi: 10.1016/S0140-6736(05)73636-9.

9. Chockalingam A., Balaguer-Vintro I., Achutti A., de Luna A.B., Chalmers J., Farinaro E., Lauzon R., Martin I., Papp J.G., Postiglione A., Reddy K.S., Tse T.F. The World Heart Federation's white book: impending global pandemic of cardiovascular diseases: challenges and opportunities for the prevention and control of cardiovascular diseases in developing countries and economies in transition. Can. J. Cardiol. 2000; 16(2): 227-229.

10. Cierniak-Piotrowska M., Marciniak G., Stańczak J. Statystyka zgonów i umieralności z powodu chorób układu krążenia. W: Strzelecki Z., Szymborski J. (red). Zachorowalność i umieralność na choroby układu krążenia a sytuacja demograficzna Polski. Rządowa Rada Ludnościowa, Warszawa 2015: 46-80.

11. Czarnecka D. Choroby układu krążenia u kobiet. W: Ostrowska A. (red.). Zdrowie i jego zagrożenia. Raport Polki 2013. Fundacja MSD dla zdrowia kobiet, Narodowy Instytut Zdrowia Publicznego - Państwowy Zakład Higieny, Warszawa 2014: 26-31.

12. Oficjalna strona Eurostatu - Statistics Explained. Eurostat - Statistics Explained > Causes of death statistics > Figure 4: Deaths from ischemic heart Disease - standardised death rate, 2014 (per 100.000 inhabitants). http:// ec.europa.eu/eurostat/statisticsexplained/index.php/File:Deaths_from_ischae mic_heart_diseases_standardised_death_rate,_2014_(per_100_000_inhabita nts)_YB17.png [dostęp: 22.05.2017].

13. Oficjalna strona World Heart Federation. World Heart Federation > Resources for Women. Hypertension.

https://www.world-heart-federa-tion.org/resources/resources-for-women/ [dostęp: 22.05.2017].
14. Gholizadeh L, Davidson P. More similarities than differences: an international comparison of CVD mortality and risk factors in women. Health Care Women Int. 2008; 29(1): 3-22, doi: 10.1080/07399330701723756.

15. Mehta L.S., Beckie T.M., DeVon H.A., Grines C.L., Krumholz H.M., Johnson M.N., Lindley K.J., Vaccarino V., Wang T.Y., Watson K.E., Wenger N.K. Acute Myocardial Infarction in Women. A Scientific Statement From the American Heart Association. Circulation 2016; 133(9): 916-947, doi: 10.1161/CIR.0000000000000351.

16. Oficjalna strona World Heart Federation. World Heart Federation > Women and CVD - facts and tips.

https://www.world-heart-federation.org/resources/women-cvd-facts-tips/ [dostep: 09.10.2017]

17. Kornacewicz-Jach Z., Olszowska M., Kopeć G. et al. Wytyczne Polskiego Forum Profilaktyki dotyczące profilaktyki chorób sercowo-naczyniowych u kobiet. Oficjalna strona Polskiego Forum Profilaktyki Chorób Układu Krążenia: http://www.pfp.edu.pl/wytyczne/kobiety.html [dostęp: 10.2017].

18. Sallam T., Watson K.E. Predictors of cardiovascular risk in women. Women's Health 2013; 9(5): 491-498, doi: 10.2217/whe.13.44.

19. Czarnecka D., Jankowski P. Choroby układu krążenia. W: Ostrowska A. (red.). Raport Polki 50+. Zdrowie i jego zagrożenia. Fundacja MSD dla Zdrowia Kobiet, Narodowy Instytut Zdrowia Publicznego - Państwowy Zakład Higieny, Warszawa 2015: 25-29.

20. Lerner D.J., Kannel W.B. Patterns of coronary heart disease morbidity and mortality in the sexes: a 26 -year follow-up of the Framingham population. Am. Heart J. 1986; 111(2): 383-390.

21. Johnston N., Schenck-Gustafsson K., Lagerqvist B. Are we using cardiovascular medications and coronary angiography appropriately in men and women with chest pain? Eur. Heart J. 2011; 32: 1331-1336, doi: 10.1093/eurheartj/ehr009.

22. Rosenfeld A.G. Treatment-Seeking Delay Among Women With Acute Myocardial Infarction: Decision Trajectories and Their Predictors. Nurs. Res. 2004; 53(4): 225-236.

23. Nguyen H.L., Gore J.M., Saczynski J.S., Yarzebski J., Reed G., Spencer F.A., Goldberg R.J. Age and sex differences and 20-year trends (1986 to 2005) in prehospital delay in patients hospitalized with acute myocardial infarction. Circ. Cardiovasc. Qual. Outcomes 2010; 3(6): 590-598, doi: 10.1161/CIRCOUTCOMES.110.957878.

24. Janion M., Janion-Sadowska A. Odrębności leczenia choroby niedokrwiennej serca u kobiet. Kardiol. Dypl. 2012; 11(11): 6-11.

25. Ahmed B., Dauerman H.L. Women, bleeding, and coronary intervention. Circulation 2013; 127: 641-649, doi: 10.1161/CIRCULATIONAHA.112.108290.

26. Krzeminska-Pakuła M. Czy płeć żeńska jest czynnikiem ryzyka w ostrych zespołach wieńcowych? Kardiol. Pol. 2011; 69(8): 793-794.

27. Mosca L., Manson J.E., Sutherland S.E., Langer R.D., Manolio T., Barrett-Connor E. Cardiovascular disease in women. A statement for healthcare professionals from the American Heart Association. Circulation 1997; 96(7): 2468-2482, doi: 10.1161/01.CIR.96.7.2468.

28. McSweeney J.C., Rosenfeld A.G., Abel W.M., Braun L.T., Burke L.E., Daugherty S.L., Fletcher G.F., Gulati M., Mehta L.S., Pettey C., Reckelhoff J.F. Preventing and Experiencing Ischemic Heart Disease as a Woman: State of the Science: A Statement for Healthcare Professionals from the American 
Heart Association. Circulation 2016; 133(13): 1302-1331, doi 10.1161/CIR.0000000000000381

29. Möller-Leimkühler A.M. Gender differences in cardiovascular disease and comorbid depression. Dialogues Clin. Neurosci. 2007; 9(1): 71-83.

30. Appelman Y., van Rijn B.B., Ten Haaf M.E., Boersma E., Peters S.A. Sex differences in cardiovascular risk factors and disease prevention. Atherosclerosis 2015; 241(1): 211-218, doi: 10.1016/j.atherosclerosis.2015.01.027. 31. Farley T.M., Meirik O., Chang C.L., Poulter N.R. Combined oral contraceptives, smoking, and cardiovascular risk. J. Epidemiol. Community Health 1998; 52(12): 775-785.

32. Zdrowie i zachowania zdrowotne mieszkańców Polski w świetle Europejskiego Ankietowego Badania Zdrowia (EHIS) 2014. Główny Urząd Statystyczny, Warszawa 2015:5. https://stat.gov.pl/obszary-tematyczne/zdrowie/zdrowie/zdrowie-i-zachowania-zdrowotne-mieszkancow-polski-wswietle-badania-ehis-2014,10,1.html?pdf=1 [dostęp: 04.2017].

33. Kośmicki M. Choroba niedokrwienna serca u kobiet - problemy diagnostyki i terapii. Przew. Lek. 2001; 4(11): 16-30.

34. Piepoli M.F., Hoes A.W., Agewall S., Albus C., Brotons C., Catapano A.L., Cooney M.T., Corrà U., Cosyns B., Deaton C., Graham I. et al. 2016 European Guidelines on cardiovascular prevention in clinical practice: the Sixths Joint Task Force of the European Society of Cardiology and Othe Societies on Cardiovascular Disease Prevention in Clinical Practice (constituted by representatives of 10 societies and by invited experts). Developed with the special contribution of the European Association for Cardiovascula Prevention and Rehabilitation (EACPR). Eur. Heart J. 2016; 37(29): 2315-2381, doi: 10.1093/eurheartj/ehw106.

35. Bellamy L., Casas J.P., Hingorani A.D., Williams D.J. Pre-eclampsia and risk of cardiovascular disease and cancer in later life: systematic review and meta-analysis. BMJ 2007; 335: 974

36. Klenk J., Keil U., Jaensch A., Christiansen M.C., Nagel G. Changes in life expectancy 1950-2010: contributions from age- and disease-specific mortality in selected countries. Popul. Health Metr. 2016; 14: 20, doi 10.1186/s12963-016-0089-x.

37. Oficjalna strona World Health Organization. World Health Organization $>$ Data > Global Health Observatory Data > GHO themes: SDG health an health related target indicators: Mortality and global health estimates > Life expectancy at birth

http://www.who.int/gho/mortality_burden_disease/life_tables/situation_trends _text/en/ [dostęp: 09.10.2017].

38. World Population Aging. United Nations, Department of Economic and Social Affairs, Population Division. ST/SEA/SER.A/348. New York 2013 31-33.

http://www.un.org/en/development/desa/population/publications/pdf/ageing/ WorldPopulationAgeing2013.pdf [dostęp: 22.05.2017].

39. Sytuacja demograficzna osób starszych i konsekwencje starzenia się ludności Polski w świetle prognozy na lata 2014-2050. Główny Urzạd Statystyczny, Warszawa 2014

40. Oficjalna strona Eurostat - Statistics Explained. Eurostat > Statistics Explained > Mortality and life expectancy statistics http://ec.europa.eu/eurostat/statistics-explained/index.php/Mortality_and_life_expectancy_statistics [dostęp: 20.04.2017].

41. Trwanie życia w $2015 \mathrm{r}$. Informacje i opracowania statystyczne. Główny Urząd Statystyczny, Departament Warszawa 2016: 15-33.

https://stat.gov.pl/obszary-tematyczne/ludnosc/trwanie-zycia/trwanie-zyciaw-2015-r- -2,10.html [dostęp: 12.2016]

42. Wojtyniak B., Stokwiszewski J., Goryński P., Zdrojewski T. Długośé życia i umieralność ludności Polski. W: Wojtyniak B., Goryński P. (red.) Sytuacja zdrowotna w Polsce i jej uwarunkowania. Narodowy Instytut Zdrowia Publicznego - Państwowy Zakład Higieny. Warszawa 2016: 49-134. 43. Oficjalna strona Eurostatu - European Commission. Eurostat > Products datasets > Healthy life years and life expectancy at birth, by sex. http://epp.eurostat ec.europa.eu/tgm/refreshTableAction.do?tab=table\&plugin $=1 \&$ pcode $=$ tsdph100\&language=en [dostęp: 09.05 .2017 ]
44. Ostrowska A. Polki 2013 - zdrowie i położenie społeczne. W: Ostrowska A. (red.). Zdrowie i jego zagrożenia. Raport Polki 2013. Fundacja MSD dla zdrowia kobiet, Narodowy Instytut Zdrowia Publicznego - Państwowy Zakład Higieny, Warszawa 2014: 9-13.

45. Kornacewicz-Jach Z., Kossuth I., Czechowska M. W kolorze serca. Go red for women. Przegląd Menopauzalny 2006; 3: 142-147.

46. Oficjalna strona Go Red for Women. Go Red for Women > Get involved. https://www.goredforwomen.org/fight-heart-disease-women-go-red-womenofficial-site/get-involved/donate-to-go-red-for-women/ [dostep: 20.09 2017].

47. Global diffusion of eHealth: Making universal health coverage achieveable. Report of the third global survey on eHealth. Global Observatory for eHealth; World Health Organization, Geneva 2016: 11-25; 27-53. http://apps.who.int/iris/bitstream/10665/252529/1/9789241511780-eng.pdf [dostęp: 20.10.2017]

48. Zielona Księga w sprawie mobilnego zdrowia (,mHealth”). COM(2014)219 final. Komisja Europejska, Bruksela 2014: 3-7. http://ec.europa.eu/transparency/regdoc/rep/1/2014/PL/1-2014-219-PL-F1-1.pdf [dostęp: 10.05.2017].

49. Davey S., Davey A., Singh J.V. Mobile-Health Approach: A Critical Look on Its Capacity to Augment Health System of Developing Countries. Indian J. Community Med. 2014; 39(3): 178-182, doi: 10.4103/09700218.137160

50. 2015 Global health care sector outlook. Common goals, competing priorities. Deloitte, 2015: 12. https://www2.deloitte.com/content/dam/Deloitte/global/Documents/Life-Sciences-Health-Care/gx-lshc-2015-health-careoutlook-global.pdf [dostęp: 20.07.2017].

51. Taylor K. Connected health: how digital technology is transforming health and social care. The Deloitte Centre for Health Solutions, London 2015; 14-15, 18-22.

https://www2.deloitte.com/content/dam/Deloitte/uk/Documents/life-scienceshealth-care/deloitte-uk-connected-health.pdf [dostep: 10.10.2017].

52. mHealth. W: From innovation to implementation. eHealth in the WHO European Region. World Health Organization, Copenhagen 2016: 40-51.

53. mHealth devices and services - analysis Global mHealth devices and services market 2016-2022. Zion Market Research. Deerfield Beach 2016: $25-27$

54. mHealth App Developer Economics 2016. The current status and trends of the mHealth app market. Research2Guidance, Berlin 2016: 12-15. https://research2guidance.com/r2g/r2g-mHealth-App-Developer-Economics2016.pdf [dostęp: 10.2017]

55. Oficjalna strona Statista - The Statistics Portal. Smartphone users worldwide 2014-2020. https://www.statista.com/statistics/330695/number-ofsmartphone-users-worldwide/ [dostepp: 20.09.2017].

56. Olok G.T., Yagos W.O., Ovuga E. Knowledge and attitudes of doctors towards e-health use in healthcare delivery in government and private hospitals in Northern Uganda: a cross-sectional study. BMC Med. Inform. Decis. Mak. 2015; 15: 87, doi:10.1186/s12911-015-0209-8.

57. Beratarrechea A., Lee A.G., Willner J.M., Jahangir E., Ciapponi A., Rubinstein A. The Impact of Mobile Health Interventions on Chronic Disease Outcomes in Developing Countries: A Systematic Review. Telemed. J. E Health 2014; 20(1): 75-82, doi: 10.1089/tmj.2012.0328.

58. Socio-economic impact of mHealth. An assessment report for European Union. GSMA. PWC 2013; 4-5, 8-13.

59. European Public Health Alliance Briefing on mobile Health (mHealth). European Public Health Alliance. Brussels 2013: 12-15.

60. Problemy. W: Zielona Księga w sprawie mobilnego zdrowia (,mHealth”). COM(2014)219 final. Komisja Europejska, Bruksela 2014: 8-20.

61. Mobile medical application. Guidance for Industry, Food and Drug Administration Staff. U.S. Department of Health and Human Services Food and Drug Administration, Center for Devices and Radiological Health, Center for Biologics Evaluation and Research. Feb. 9, 2015: 4-18.

62. mHealth - New horizons for health through mobile technologies. Global Observatory for eHealth series - Volume 3: 1-7. 